\title{
Heritage research in the 21 st century: departing from the useful futures of sustainable development
}

\section{Višnja Kisić}

At the beginning of the 20th century, Dadaists were shouting, 'ruin the museums and heritage'. Near the end of it, Fukuyama (1989) prophetically questioned 'the end of history', while museum, heritage and memory rituals were becoming all but unavoidable. In the last two decades, in the wake of occupied and uncertain futures, the heritage field has boomed. Hundreds of museums have opened each year across the globe; heritage tourism has become an ever-stronger industry niche; heritage issues have made it into numerous policy areas other than culture; heritage studies have become an immensely dynamic and interdisciplinary field; heritage practices have extended their scope, aspirations and approaches with each new day; and conflicts in numerous parts of the world have incorporated references to heritage and history. Questions that have been raised and continuously discussed in these decades have transformed both heritage practice and research. What counts as heritage? Who has the right to define, safeguard and transform it? What is the role of memory institutions in ever more plural and fragmented memory landscapes? Which knowledges, skills and competences are needed to be engaged in heritage practice, professionally and otherwise? How is heritage to be understood and cared for?

These and other questions have challenged the long-standing, Western European, hegemonic way of understanding and practising heritage. The push for critical reassessment within the heritage profession, the new museology (Vergo 1989; Desvallées 1992; Desvallées 1994; Bennett 1995; Duncan 1995; Kisić 2014), and (critical) heritage studies (Smith 2006; Harrison 2013; Waterton and Watson 2013; Winter 2013), as well as perspectives from non-Western societies and subaltern groups within Western societies, have led to new research agendas. These understand memory institutions and 
heritage as a particular mode, method and discourse entangled with structural, systemic and symbolic forms of power. Moreover, the neoliberal turn of the global capitalist order in public policies and research has pressured the heritage field in research and practice to open up to other-than-public actors, new instrumentalisations and integrations with dominant development agendas. This book, together with the increasing amount of research in heritage studies, recent policy documents and growing heritage practice, reflects the ongoing shift towards other ways of framing, creating, doing and engaging with heritage, which I have termed the inclusive heritage discourse (Kisić 2016). This addresses the multiple openings of the authorised heritage discourse that have taken place in the last few decades. Those openings and shifts have paved the way for a myriad of critical, democratic, plural and emancipatory struggles in conceptualising, researching and practising heritage. However, many of them have been embraced by a new pragmatism that leans on neoliberal global capitalist developments.

Simultaneously, with the strengthening of critical heritage studies, there has been an even stronger trend towards research with utilitarian, practical and measurable results - research that will be instrumental for how societies relate to heritage, how policies are drawn and how heritage is managed. It is in this light that I have considered this invitation to write this chapter. This book gathers projects funded through particular calls and agendas focusing on heritage and its social, environmental and economic impact. As such, it is representative of a particular moment and a particular hegemony in the European research field and is thus symbolic in both in its diversity of topics and its common assumptions. What unites most of the research gathered in this book is explicit and often implicit dialogue with sustainable development, a poster child of the neoliberal capitalist order which currently shapes European and world research imaginations.

Taking into consideration these shifts in heritage discourse, as well as a particular heritage-view in relation to the dominant sustainable development paradigm implicated in this book, I will engage in a dialogue with the three themes set by the editors in relation to heritage - Identity, Climate and Development. In this discussion, my aim will be to shed light on some possible understandings of heritage within the complex web of life and socio-political relations, which offer alternatives to its current position within the sustainable development paradigm. I will therefore be trying to imagine other possible worlds and futures beyond the one prophesied by sustainable development; worlds in which the crises of today's integrated world capitalism, of risk societies in a state of permanent global war and of humans' colonial relationship to the otherness in the web of life, ask us to formulate heritage issues in 
a different way. By doing so, I will position each of the three broader themes within a particular field of problematisation that could shed light on possible divergent approaches and theories, as well as divergent political and ethical agendas for the heritage field, beyond what I would call useful futures. By useful futures I mean a specific kind of sensibility, mindset and governmentality that evaluates lives, bodies, creative forces, relations, spaces and times as resources deemed more or less useful for the sustaining of the current world order, and the imaginations by which that order perpetuates itself. Global capitalism - linked with the sustainable development paradigm, with its peculiar discourse on exponential growth, climate change, social cohesion and struggle against poverty, and its set of goals, measures, evidence-based methods and techno-optimism - produces the mentality of useful futures, thus eliminating multiple possible worlds and narrowing down alternative conceivable futures.

In an attempt to go beyond useful futures of sustainable development, I will discuss the entanglements between heritage and identity by relating them to debates on hegemony and pluralism. In discussing the issue of heritage and climate, I will reformulate the debate to include many more issues of heritage with(in) the environment, involving questions of human/non-human agency, care and decay and the interconnectedness of the symbiotic real. Finally, I will explore the relationship between heritage and development, through the lenses of heritage as a commodity and heritage as commons. Those three trajectories will help guide my reflection on the current ways of framing the heritage field in relation to identity, environment and development. Simultaneously, they will act as glimpses of some of the alternative ontological, ethical, ecological and political routes relevant for the future of heritage research in possible future worlds.

\section{Hegemonies and pluriverse: thinking identifications, dissonances and engagements}

Heritage-making, heritage-doing and the processes of identifying and subjecting oneself to heritage are inherently political. They are predicated not only on questions of who is included, but with what rights and under what terms, visions, implications and arrangements. Each identification with heritage implies subjectification to a particular narrational chain of history (Connerton 1989), to a particular distribution of the sensible (Ranciere 1999) and to particular regimes of engagements with past, present and future. Heritage-making and heritage-doing go hand in hand with creating and consolidating both localised and imagined communities (Anderson 1983; Waterton and Smith 
2010; Arronson and Elgenius 2015), thus normalising identities, differences and power relations (Hall 1999). These relationships between heritage, identity and power have been at the forefront of critical scholarship in heritage studies since the 1980s. Much has been written about heritage as a mechanism of modern Western European governmentality and hegemony (Handler 1987; Hooper-Greenhill 1992; Smith 2006; Bennett et al. 2017); a powerful sustaining mechanism for naturalising Western ways of ordering societies, relating to otherness and envisaging futures. Moreover, the heritage practices, perspectives and realities of diverse subaltern groups have been voiced: not just to be included in the hegemonic ways of doing heritage, but to redefine regimes of imagination and legitimacy in doing it. The wider post-1989 context, characterised by increased construction and politicisation of identity-based difference, has further questioned the universalising, apolitical governmentality of heritage, exposing it as a site of social struggles, negotiations and conflicts.

Furthermore, efforts to address the 'democratic deficit' and the pluralisation and fragmentation of societies in Europe have triggered a participatory turn in heritage practice, politics and research. Much of the recent research exploring the entanglements between (European) heritage, identity and memory suggests that these categories and processes should be seen as multidirectional, plural, conflictual and divergent, rather than as consensual, celebratory and coherent (Kisić 2018b). Moreover, relationships with heritage have been conceptualised beyond cognitive registers; trying instead to understand engagements with heritage as navigated through the politics of affective registers such as pain, loss, joy, nostalgia, pleasure, belonging or anger (Tolia-Kelly et al. 2016).

In some heritage research, a critique of and shift from ontological essentialism and positivist epistemology has opened new horizons for thinking about the hegemonising force of heritage-making, as well as its potential to disrupt, challenge and contest hegemonic ways of ordering identities, societies and ecosystems. What is being constructed as a consequence is what I define as the inclusive heritage discourse. This reflects the multiple openings which have taken place in the last few decades - such as the multitudisation of actors, pluralisation of meanings and pluralisation of ways of constructing relationships with the past. In this discursive construction, heritage has been increasingly understood as an interpretative, communicative process continuously (re)constructed in the present by relating values, beliefs and meanings with diverse forms of materialisations. Instead of a single truth about the past, mediated through material remains, the inclusive heritage discourse appraises the plurality of meanings related to heritage, and acknowledges dissonance as a quality embedded in heritage-making. As such, I argue for understanding heritage values as relational and instrumental for a myriad of identity-based, 
political, economic, social and cultural goals. This recognises an assemblage of diverse actors in governing heritage and links the right to heritage with agency across social groups, together with diverse choices and responsibilities in using it - including destruction, forgetting or alteration. Finally, it reflects the transition from a static understanding of heritage that legitimises only conservation, towards a dynamic understanding of heritage as a way of negotiating change and continuity. This discursive shift, however, not only accommodates emancipatory heritage struggles; it simultaneously neutralises and naturalises neoliberal hegemony by justifying austerity measures, heritage-led development and commodification of heritage.

The opening of heritage as a plural and conflicting ground (Kisić 2018a) has been met by diverse strategies of governing dissonance, creating closures and manufacturing consent, such as:

1. Entrepreneuring dissonance and subalternity - in which new ways of consuming and entrepreneuring heritage experiences have become ever more diverse and have expanded the horizons of tourism and leisure towards industrial heritages, dark and difficult heritages, localised gastronomies, off-the-beaten-track narratives and more than public actors (Veldpaus and Wacogne, Chapter 6 this volume). At the same time, new practices of inclusion and exclusion are brought in, entangled with economic interests.

2. Occupying the common(s) as a place of consent - in which the concept of shared or common (European) heritage has been increasingly positioned as a more plural substitute for the universalist concept of heritage, manufacturing a specific kind of consent on supranational identity, in which many might be included, but do not 'naturally' belong (migrants, Roma, sans papiers, diasporas, etc.) - as Fiorentini et al. show in Chapter 8 this volume. This notion not only excludes some from forms of identifying, but excludes everyone from practices of communing heritage, as I will discuss later.

3. Exceptionalising ruptures, participations and inclusions - in which inclusions, participations and ruptures in hegemonic historic narratives and authorising institutions have been kept at the level of temporary, project-driven and non-sustaining occasions and exceptions. Thus, talking about, experimenting with and researching subaltern voices and participatory models take place behind the powerful backdrop of sedimented historic narratives and practices, as Whyton and Perry show in Chapter 14 this volume.

4. Exporting conflicts to peripheries and pasts - in which heritage-related conflicts, as well as heritage-led reconciliation practices and research, have been exported to certain geographies on European peripheries (the 
Yugoslav successor states and Northern Ireland) or to certain time periods in the European past (World Wars, the Holocaust, fall of the Berlin Wall). This implies the absence of socio-political and economic conflicts, and their entanglements with heritage, in European centres (Kisić 2019).

5. Ghettoising dissonances, difficulties and discomforts - in which numerous concepts have been proposed to pinpoint the upsetting, conflictual characteristics of heritage: dissonant (Tunbridge and Ashworth 1996), difficult (Macdonald 2009), contested (Silverman 2011) and unwanted (Light 2000), among others. These concepts often serve to depoliticise heritage dissonance through ghettoisation, standardisation, consonance and psychological pluralisation (Kisić 2018b). Each of these strategies of closure and hegemonising remain to be further addressed in future research.

Apart from these research avenues, future heritage research and practice could be called upon to address the growing number of ways in which heritage works beyond current strategies of closures and consent; ways in which heritage opens and enables new forms and kinds of identifications and pluralisations that could be grasped by concepts of dissensus, alliances, conflicts and multitudes. Here is just a glimpse of the myriads of these alternative ways.

Instead of sealing off pluralism by naming some heritage as 'dissonant', the notion of heritage dissonance (Kisić 2016) opens broader horizons for questioning sedimented, policed heritage narratives and practices (Kisić 2018b). This enables us to notice ever-present instabilities, resurgences and subaltern ways of remembering within heritage practices, as well as the ways in which the dominant order is obscuring and obliterating them. The concept of agonistic pluralism (Mouffe 2013), similarly, can make space for politics and knowledge that values disagreements and acts of dissensus, rather than delineating clear and consensual political wholes. This is a lens that encourages us to understand and address the conflicts reflected and embedded in heritage and to practise heritage on a more democratic level. Moreover, instead of the overused, rigid notions of community, class, group, ethnicity and people, the concept of the multitude (Hardt and Negri 2004) might offer more promising horizons for addressing emancipatory alliances in heritage-making as 'singularities that act in common': internally multiple, irreducible to a single hegemonic stand and in a constant process of becoming. Together with concepting rights to heritage, new research should also notice and address practices of dis-identification: 'maintaining a distance' from one's symbolic identity and emancipating oneself from oppressive practices (Butler et al. 2000). Finally, heritage researchers might start trading in worn-out universalist epistemologies for those that embrace the plural epistemologies and pluriverse (Escobar 2018). This could open up our imaginations for fundamentally different knowledge creation and 
political subjectification that might pave ways for radically interconnected and life-pulsating futures.

\section{Heritage with(in) environment: thinking existences, interrelations and agencies}

Engaging in research that opens plural future alternatives requires us to pose ontological questions on existence and interconnectedness, as well as on socio-economic regimes with which our existences, participations and identities are intertwined. However, the narrative in which heritage is endangered by the hostile force called Climate that is changing beyond our control and understanding closes multiple horizons. It sees climate as somewhat external to both humans and heritage sites, and assumes the ideas of managing change, mitigating risks, monitoring, tracking and taking back control - all within current socio-political arrangements. By embedding and internalising such a discourse, heritage research blinds us to the very epistemic, ethical and political roots of our current regimes of worlding. Swyngedouw (2010) interprets this focus on the 'Spectre of Climate Change' as a post-political normalisation of the current neoliberal order and economic practice, which prohibits thinking about alternative ways of organising society, distributing resources and relating to the environment.

The stream of articulating our relationship with the environment through the threat of climate change has produced important research results, policy papers and expert reports that address the effects of natural disasters and the cumulative effects of changing weather on material heritage (Colette 2007; Sobbioni et al. 2010; ICOMOS 2019; also the projects presented in this volume). However, heritage research and theory have taken diverse other paths in thinking of heritage (with)in environment. As a field long preoccupied with collecting and protecting against loss and for the future, heritage research has addressed the challenges that heritage practices face beyond preservation. The critique of the dominant practices of collecting and listing heritage, entangled with the development of capitalist object relations, gave rise to writings about de-accessioning (Vecco and Piazzai 2015) and de-growth as applied to heritage (Morgan and Macdonald 2018). Furthermore, heritage planning has recognised ideas of adaptive reuse, heritage rehabilitation and managing historic urban landscapes (Pereira Roders and Bandarin 2019). Also, virtual, augmented realities and digitalised heritage are seen by some as a way forward, transgressing the logic of materiality, authenticity and objecthood, while in reality promoting other kinds of objecthood mediated by technolog- 
ical devices. On the other hand, virtuality is all but simple in research which illuminates the ways that natural heritage and endangered species, seeds and genetic material are being preserved through ex situ practices, biobanking and biocapitals (Breithoff and Harrison 2018).

The notion of protection against loss has been challenged by DeSilvey's (2017) concept of practising 'curated decay' as a way to reframe the heritage field towards examining the persistence of decay as a product of natural and cultural circumstances, widening the agency of human and non-human actors. In the time of the Anthropocene and the effects of climate change, Harvey and Perry (2015) argue we need a new understanding of heritage which embraces loss, alternative forms of knowledge and uncertain futures, and which fosters the creativity and adaptability of future generations. Thinking about heritage within its environment has opened possibilities for understanding and exploring the changing relations of humans with their environment, as Valerani and Visentin (Chapter 10 this volume), as well as Tully and Moore (Chapter 5 this volume) reflect. Instead of curating decay or arguing for preservation or conservation against climate change, participation in heritage could stimulate engagement in landscape choices and relatedness to diverse forms of being, reviving practices. Moreover, landscape is not understood only in relation to those who can claim roots and settlements in it, but also those who are engaging with it through routes, while on the move (Bender 2001).

Along those lines, when addressing heritage within the environment, new research paths in heritage could reframe explorations in dialogue with other philosophical, political and ecological thinking that interpret the current hegemonic discussion on climate change and ecology in a different way. This would entail thinking about the relationships between human and non-human beings and agencies, and what these mean for the current understandings of existences, boundaries, identities and hierarchies that shape our current understanding of the world. If perspectivism and constructivism have opened the epistemic basis of heritage research to a plurality of actors, interpretations, valorisations and ways of knowing, the actor-network theory (Latour 2005) and object-oriented ontologies (Morton 2013, 2017; Harman 2018, 2019) have challenged the very idea of heritage as solely a human discursive-interpretative construction, opening new ontological horizons for multiple coexisting realities, becomings and interconnections (Mol 1999). Consequently, this ontologically puts into question the concepts and practices which understand heritage sites, objects, landscapes and practices as delineable, bounded entities subjected to control, management and adaptive reuse through human agency. 
The ontological implications of theories and concepts such as symbiotic real and subsendence that posit ontological interdependence of beings (Morton 2017); ecosophy that interrelates the ecological registers of environments, social relations and subjectivities (Guatarri 2000; Antonioli 2018); or matters of care that are implied in our very coexistence within more than human worlds (Puig de la Bellacasa 2017) challenge the very ideas of isolated subjectivities, nature-culture divides, managerialism, universalism and speciesism. Abstract as they may sound, these implications deeply influence the ways in which we understand life on this planet, and consequently the (ontological) politics, ethics and practice of researching and doing heritage. Are spaces, objects, plants or rocks legitimate existences accounted for beyond human needs? Is heritage practice, in claiming to care for future worlds while safeguarding pasts, at the same time colonising other possible future worlds by putting (some) humans first? What would the notions of informality, solidarity and interdependence imply in planning and heritage doing? What would the role of heritages be in de-universalising, re-territorialising and re-aestheticising planning practices beyond the sustainable development paradigm towards subjective cities (Guatarri 2019)? What would the incorporation of place-based ethics (Till 2012), experiences, memories, existences and subjectivities mean in heritage planning when engaging in urban or environmental change practices as planners, heritage managers or urban theorists? When planning change in historic (urban) landscapes, what would it mean to think, research and plan spaces not occupied by humans beyond 'empty', 'unused', 'lacking content' or simply 'green'? What would equality with non-humans imply for the discrepancy between archaeological practices and careful treatment of human remains, in contrast to the drilling and burning remains of other life forms through fossil fuel consumption? Should we understand biobanks as places for 'securing hope' (Harrison 2017) in the context of the human-induced entropic decay of diversity, or as the engineering of a useful future in which species, seeds and life are purposefully destroyed, while simultaneously being stored in case they are deemed useful for the future of humanity? The future planned so that many other-than-human beings might not exist, but depositing institutions will?

\section{Heritage as commodity and heritage as commons: thinking divergent visions of development}

The mentality of the useful future not only shapes our approaches to understanding heritage within webs of life, but deeply influences and is influenced 
by the very notions of development that we are able to imagine and practice in relation to heritage - the development increasingly saturated by the commodified future. The 'economies of worth' (Boltanski and Thevenot 2006) knocked on the door of heritage research decades ago, and some of the doors were opened wide for exploring the justification of heritage: its worth, its impact, its value and its usefulness for the current model of society. As Janssen et al. (2017) note, the infiltration of economic and social concerns is subtly altering the way heritage is dealt with spatially, paving the way for heritage in spatial planning with a 'culture of profit' in which heritage fosters social and economic development (Corten et al. 2014). As Veldpaus and Wacogne note in Chapter 6 this volume, there is 'an increased focus on pragmatic and highly selective heritage practices, or in other words on "useful" heritage' - practices which, in order to be legitimate under the growth agenda, have to legitimise the growth agenda themselves by facilitating and stimulating growth through heritage conservation. The excuses for justifying the shift are numerous: austerity measures and reduced funds for conservation of historic buildings; competitiveness between cities, regions and countries on the global experience market; the shift towards evidence-based policies in shrinking welfare states; the move towards sustainable development, resilience and smart cities. Almost naturally and inevitably, heritage practice and heritage research are mainstreaming heritage in other policy agendas, finding new integrated models for managing heritage, pioneering regeneration of neighbourhoods, producing spill-over effects and, in particular, 'highlighting the returns on investments in conservation beyond the narrow circle of the heritage sector' (Della Torre and Moioli, Chapter 15 this volume).

In most of today's Europe, we live the reality in which the statement, 'heritage is a globalised economic commodity', is a doxa of a good part of the heritage planning and heritage research agendas. Consequently, the development language of capital and resource occupy our research vocabularies and methods when it comes to peoples, communities, humans, territories, cultures, and other living and non-living beings. The research presented in this book is all but immune to this terminology; that is, utilising notions of human capital, cultural capital, upstream investments and spill-over effects to talk about the ways in which heritage shapes our realities, economies, social relations and futures. Other research has followed this trend: a growing literature on the social and economic value of heritage (Dümcke and Gnedovsky 2013), as well as a new synthesis of its impact on sustainable development (CHCfE, van Balen and Vandesande, Chapter 3 this volume), together with research projects that focus on defining and measuring the impacts of material cultural heritage on other economic sectors. Furthermore, a whole niche of heritage research has boomed, exploring the relationship between heritage, develop- 
ment and tourism (Timothy and Boyd 2006; Salazar 2010; Ashworth 2014). In mapping the impact of heritage, the amount of research on economic impact far surpasses the studies which have explored social, cultural and environmental impact (CHCfE Consortium 2015, 14). The new orthodoxy of heritage-led development and impact assessment has been criticised; not only for focusing on one aspect of impact (CHCfE), but for suffering from a positivist bias (Labadi 2008), for gentrifying places (De Cesari and Dimova 2019) and for segregating areas and people whose daily lives are being shaped by these developments (Leite 2013). An even bigger epistemic, political and structural problem with this trend is that, while seemingly universalist and objective, this research comes with a whole set of unquestioned political and economic assumptions, geopolitical power relations and historic contingencies. These serve to further institute neoliberal capitalism in Europe, in European countries 'in transition' and globally. The majority of studies on the impact of heritage in Europe have been performed in the UK and several other late-capitalist countries of Western Europe, together with some pioneering cases in Eastern and Southern Europe. However, despite the particular situatedness of the best practices, the evidence-based research and funding logics are being benchmarked into international, national and local policies and transposed into contexts in which their promises are hard to realise. Thus, I argue that the global structural injustice previously performed by the intrinsic worth of Western European heritage, in delineating more from less civilised, is today performed by the techniques of instrumental worth in heritage-led development on the global markets.

This doxa of heritage commodification for development, however, is increasingly haunted by the idea of the commons (van Laerhoven and Ostrom 2007; Hardt and Negri 2009; Harvey 2012), in a counter-capitalist development struggle by numerous groups. What the above-mentioned research defines and normalises as the foundational entanglement between heritage and a particular type of economic development, writings on heritage as commons understand as the deepening of alienation and inequality entailed by the appropriation of commons through heritage construction and commodification. Reworking the idea of the commons in relation to heritage, Gonzáles (2015) argues that the heritagisation process relies on and draws from the 'common givens' - the common wealth of the material world, as well as the results of social production such as traditions, knowledges, languages, codes and affects co-created by unspecified subjectivities during time. Furthermore, the heritage givens are becoming a 'productive force', put to work through novel assemblages of value creation; some of which foster the further creation of commons, while others prevent it by appropriating and capturing the common heritage values to generate profits (and other non-communal political, economic and social ends). In the wake of knowledge and experience economies, the renting and 
capitalising of the common creative forces entailed in heritage processes are expanding their horizons - through delineation and commodification of 'intangible' heritages; heritage digitalisation within growing copyright markets; heritage-based place branding that capitalises artiness, multiculturality or rawness of localities; or market and policy entanglements of cultural diversity with creative industries. The widening of the scope and meaning of heritage in the name of democratisation and inclusion has also expanded the frontiers of its enclosure and exploitation by capital.

Understanding heritage as a commodity and heritage as commons is not just a matter of an author's or manager's 'preferences as to the best ways to manage them' (Barrère 2018). It is a matter of ethical, political and ontological assumptions that lead to irreconcilably different frameworks of interpretation of heritage within the current world order, its possible transformations and futures. Unlike the careful classification of social, economic, cultural, environmental and other impacts in commodifying heritage, understanding heritage as commons implies understanding value creation, material distribution and the social relations in which they take place as inextricably bound to each other. In the context of global capitalism and neoliberal politics, with austerity measures in public goods and the transformation of public goods into means for private capital accumulation (Hardt and Negri 2009), the idea of entrusting states with the public goods implied in the ideas of the common heritage of humanity in international law (Balsar 2012), or world heritage, is being questioned. Therefore, the practice of communing is seen as a new negotiation between citizens, state and capital, in which the commons have to be enacted anew. This is done by social groups reclaiming and redefining 'those aspects of their actually existing or yet-to-be-created social and/or physical environment deemed crucial to its life and livelihood', as 'collective and non-commodifiable' (Harvey 2012, 73). Understanding heritage as commons, and interpreting the enclosure and commodification of heritage beyond post-political neutralising registers of growth and development, opens different horizons for analysing heritage economies as inextricably intertwined with social, communal, environmental and cultural struggles.

There have been many engagements with the idea of the commons, and the historic and contemporary heritage practices aligned with it, but these are often left under the radar of mainstream ways to understand and research heritage. The most discussed current examples consist of urban struggles, in which heritage as commons has been increasingly vivid in movements claiming the 'right to the city', and numerous community groups that work on imagining new urban commons (Benesch et al. 2015; Sham 2017). They do this by fighting for housing rights, for spaces free from monetary exchange and against 
the commodification of neighbourhood memories, spaces and views. Beyond struggles for the right to the city, numerous existing campaigns could be better understood through the idea of constructing heritage as commons than through notions of commodity, logics of usefulness and economies of worth: community-cared heritage sites, oral history groups, community archives, family practices of heritagisation, Internet practices and virtual spaces that store and make knowledge and information accessible, or campaigns against further exploitation of public spaces and landscapes. In the museum field, a number of practices which started in the late 1960s and 1970s in rural areas and suburbs - such as ecomuseums, integral museums and community-run museums - have experimented with new forms of place-based museums as a method for navigating communal futures, by interrelating heritage, citizens, environments and processes of value creation. Furthermore, the struggles of indigenous communities for acknowledgement of their heritage could be understood beyond the effort for their cultures to be recognised within the Westernised idea of heritage in a cognitive level of significance assessment, as an effort to negotiate ideas of common place, common life, common territory and common development against the colonising statist-capitalist world order. In all these initiatives, the struggles are not about the right to be included in the valorisation, commodification and planning processes formulated by the current order, but about the right to be exempt from it, while at the same time broadening the horizon of possible arrangements.

In the increasing intellectual production and heritage practices that align with the current economies of worth and evidence-based justification of worth, researching heritage as commons could point to alternative horizons by several paths. One possible path would be genealogical analyses which explore the historic entanglements between environments, social groups, creative forces and power structures, thus denaturalising capitalist enclosures and exploitations, while pluralising alternative historic routes of ownership, care and production. ${ }^{1}$ In heritage practice, this would entail acknowledging, memorising and interpreting practices, groups, personalities, places and moments of rupture which tell alternative stories about ways of organising life and social production in diverse territories. Furthermore, research would require recognising and interpreting both historic and existing heritage practices from the perspective of the commons; researching those efforts that understand heritage-making as

Such is the recurring interest in valorisation of Yugoslav heritage and the socialist arrangements instituted and practised in the Socialist Federative Republic of Yugoslavia after the 1974 Constitution. These include social property as a framework for use and care for resources and production, managed by self-organised communities of workers in a type of participative democracy. 
commons and those that negotiate knowledge and historic spaces as places of the commons. Finally, the important work pursued by critical heritage studies in relation to the struggles for recognition of subaltern heritages and contestations of the authorised heritage discourse should be expanded beyond identity politics, to incorporate questions of economic arrangements, structural inequalities and spatial entanglements in the processes of understanding, creation and negotiation of heritage.

\section{Conclusion: thinking topics, frameworks and arrangements for future heritage research}

Thinking about the future research agenda for heritage, the discussion over what gets on the agenda in terms of themes, issues and methods should not preoccupy us more than the questions of how we get to think about and do research in the future, as well as who gets to do it. We will discuss this in more detail in the final chapter of this book. Amid increasing neoliberalisation and the intertwinement of integrated global capitalism with science, research and education (Lynch 2006), funding for heritage research comes with a narrowing of research agendas to focus on particularly 'useful research' for the needs of the state, supra-national and commercial actors; on 'desirable research' within the context of current geopolitics; and on the research topics that privilege or disadvantage certain actors as research subjects.

Dominant funding and market frameworks and agendas, however, not only define the form in which production of knowledge takes place, but narrow down the space for intellectual imaginations, locking out alternative possible worlds through the research we do, the questions we pose and the ways we observe. The most problematic aspect of research produced through such arrangements is not the research itself, but everything that is left out - questions that have not been explored because of the how and who of research arrangements. For these reasons, thinking new research agendas requires us to also think new research arrangements and new ways of subjectivising ourselves as researchers; because the very choices of the forms of knowledge regulation influence the ways in which we are able to think, feel and imagine. 


\section{References}

Anderson, B. (1983), Imagined Communities: Reflections on the Origin and Spread of Nationalism, London: Verso.

Antonioli, M. (2018), 'What is ecosophy?', European Journal in Creative Practices in Cities and Landscapes. Accessed 15 October 2019 at: https://cpcl.unibo.it/article/ view/8587/8334

Aronsson, P. and G. Elgenius (eds) (2015), National Museums and Nation-building in Europe 1750-2010. Mobilization and Legitimacy, Continuity and Change, London: Routledge.

Ashworth, J.G. (2014), 'Heritage and economic development: Selling the unsellable', Heritage and Society, 7 (1), 3-17.

Barrère, C. (2018), 'Cultural heritage: Capital, commons, and heritages', in A.M. Labrador and N. Asher (eds), The Oxford Handbook of Public Heritage Theory and Practice, New York: Oxford University Press, pp. 139-54.

Baslar, K. (2012), The Concept of Common Heritage of Mankind in International Law, The Hague, Boston and London: Martinus Nijhoff Publishers.

Bender, B. (2001), 'Landscapes-on-the-Move', Journal of Social Archaeology, 1 (1), 75-89.

Benesch, H., F. Hammami, I. Holmberg, and E. Uzer (eds) (2015), Heritage as Common(s), Common(s) as Heritage, Gothenburg and Stockholm: Makadam Publishers.

Bennett, T. (1995), The Birth of the Museum. History, Theory, Politics, London and New York: Routledge.

Bennet, T., F. Cameron, N. Dias et al. (2017), Collecting, Ordering, Governing: Anthropology, Museums and Liberal Government, Durham, NC: Duke University Press.

Boltanski, L. and L. Thevenot (2006), On Justification: Economies of Worth, Princeton, NJ and Oxford: Princeton University Press.

Breithoff, E. and R. Harrison (2018), 'From ark to bank: Extinction, proxies and biocapitals in ex-situ biodiversity conservation practices', International Journal of Heritage Studies. Available 15 October 2019 at: https://www.tandfonline.com/doi/full/10 $.1080 / 13527258.2018 .1512146$

Butler, J., E. Laclau and S. Žižek (2000), Contingency, Hegemony, Universality: Contemporary Dialogues on the Left, London and New York: Verso.

CHCfE Consortium (2015), Cultural Heritage Counts for Europe, Krakow: International Cultural Centre.

Colette, A. (ed.) (2007), Climate Change and World Heritage, UNESCO World Heritage Reports 22.

Connerton, P. (1989), How Societies Remember, Cambridge: Cambridge University Press.

Corten, J.-P., E. Geurts, P. Meurs and R. Vermeulen (eds) (2014), Heritage as an Asset for Inner-City Development, Rotterdam: NAi010.

De Cesari, C. and R. Dimova (2019), 'Heritage, gentrification, participation: Remaking urban landscapes in the name of culture and historic preservation', International Journal of Heritage Studies, 25 (9), 863-9.

Desvallées, A. (ed.) (1992), Vagues: Une Anthologie de la Nouvelle Museologie, vol. 1, Paris and Macon: Éditions W.M.N.E.S. 
Desvallées, A. (ed.) (1994), Vagues: Une Anthologie de la Nouvelle Museologie, vol. 2, Paris: Savigny-Le-Temple: M.N.E.S.

DeSilvey, C. (2017), Curated Decay: Heritage Beyond Saving, Minneapolis, $\mathrm{MN}$ : University of Minnesota Press.

Dümcke, C. and M. Gnedovsky (2013), The Social and Economic Value of Cultural Heritage: Literature Review, EENC Paper.

Duncan, C. (1995), Civilizing Rituals. Inside Public Art Museums, London: Routledge.

Escobar, A. (2018), Designs for the Pluriverse: Radical Interdependence, Autonomy and the Making of Worlds, Durham, NC and London: Duke University Press.

Fukuyama, F. (1989), 'The end of history?' The National Interest, 16, 3-18.

González, P.A. (2015), 'Conceptualizing heritage as a common', in P.F. Biehl, D.C. Comer, C. Prescott and H.A. Soderland (eds), Identity and Heritage: Contemporary Challenges in a Globalized World, Heidelberg, New York, Dordrecht and London: Springer, pp. 27-35.

Guattari, F. (2000), The Three Ecologies, London and New Brunswick, NJ: The Athlone Press.

Guatarri, F. (2019), 'Pratiques écosophiques et restauration de la cité subjective', Chimeres, 17, 1-18. Accessed 15 October 2019 at: https://www.revue-chimeres.fr/ Chimeres-17-Pratiques-ecosophiques-et-restauration-de-la-Cite-subjective.

Hall, S. (1999), 'Whose heritage? Un-settling "the heritage", re-imagining the Postnation', Third Text, 13 (49), 3-13, https://doi.org/10.1080/09528829908576818.

Handler, R. (1987), 'Review: heritage and hegemony: Recent works on historic preservation and interpretation', Anthropological Quarterly, 60 (3), 137-41.

Hardt, M. and A. Negri (2004), Multitude, London and New York: Penguin Random House.

Hardt, M. and A. Negri (2009), Commonwealth, Cambridge, MA: Harvard University Press.

Harman, G. (2018), Object-Oriented Ontology: A New Theory of Everything, London: Pelican.

Harman, G. (2019), 'Hyperobjects and prehistory', in S. Souvatzi, A. Baysal and E.L. Baysal (eds), Time and History in Prehistory, London: Routledge, pp. 195-209.

Harrison, R. (2013), Heritage: Critical Approaches, Abingdon: Routledge.

Harrison, R. (2017), 'Freezing seeds and making futures: Endangerment, hope, security, and time in agrobiodiversity conservation practices', Journal of Agriculture and Environment, https://anthrosource.onlinelibrary.wiley.com/doi/full/10.1111/cuag .12096

Harvey, C.D. and J. Perry (2015), The Future of Heritage as Climates Change: Loss, Adaptation and Creativity, New York: Routledge.

Harvey, D. (2012). Rebel Cities: From the Right to the City to the Urban Revolution, London and New York: Verso.

Hooper-Greenhill, E. (1992), Museums and the Shaping of Knowledge, London and New York: Routledge.

ICOMOS (2019), The Future of Our Pasts: Engaging Cultural Heritage in Climate Action, July 1, 2019, Paris: ICOMOS.

Janssen, J., E. Luiten, H. Renes and E. Stegmeijer (2017), 'Heritage as sector, factor and vector: Conceptualizing the shifting relationship between heritage management and spatial planning, European Planning Studies. Accessed 15 October 2019 at: https://www.researchgate.net/publication/317118439_Heritage_as_sector _factor_and_vector_conceptualizing_the_shifting_relationship_between_heritage _management_and_spatial_planning 
Kisić, V. (2014), 'Stvaralac, saučesnik, konzument: ka okvirima mnogostrukih lica učešća građana u stvaranju baštine' (Creator, participant, consumer: Understanding multiple frameworks of citizens' involvement in heritage-making), Kultura 144: New Museology, 106-27.

Kisić, V. (2016), Governing Heritage Dissonance: Promises and Realities of Selected Cultural Policies, Amsterdam: European Cultural Foundation.

Kisić, V. (2018a), 'Shaking the solid - heritage in the era of plurality', in A.-M. Halme, T. Mustonen, J-P. Taavitsainen, S. Thomas and A. Weij (eds), Heritage Is Ours: Citizens Participating in Decision Making, Helsinki: Europa Nostra Finland, pp. 134-42.

Kisić, V. (2018b), 'Beyond celebrations and divisions: Re-politicizing heritage dissonance in Europe', Economia della Cultura, 4/2018, 465-78.

Kisić, V. (2019), 'Reconciliation through cultural heritage in the post-Yugoslav space: An apolitical endeavor', in S. Labadi (ed.), The Cultural Turn in International Aid: Impacts and Challenges for Heritage and the Creative Industries, London: Routledge, pp. 173-92.

Labadi, S. (2008), Evaluating the Socio-economic Impacts of Selected Regenerated Heritage Sites in Europe, Amsterdam: European Cultural Foundation.

Latour, B. (2005), Reassembling the Social: An Introduction to Actor-Network Theory, Oxford: Oxford University Press.

Leite, R.P. (2013), 'Consuming heritage: Counter-uses of the city and gentrification', Vibran: Virtual Brazilian Anthropology, 10 (1), 165-89. Accessed 15 October 2019 at: http://www.scielo.br/scielo.php?script=sci_arttext\&pid=S1809 $-43412013000100009 \& \operatorname{lng}=$ en\&nrm $=$ iso

Light, D. (2000), 'An unwanted past: Contemporary tourism and the heritage of communism in Romania', International Journal of Heritage Studies, 6 (2),145-60.

Lynch, K. (2006), 'Neo-liberalism and marketisation: The implications for higher education', European Educational Research Journal, 5 (1), 1-17.

Macdonald, S. (2009), Difficult Heritage: Negotiating the Nazi Past in Nuremberg and Beyond, New York: Routledge.

Mol, A. (1999), 'Ontological politics. A word and some questions', in J. Law and J. Hassard (eds), Actor Network Theory and After, Malden, MA: Blackwell, pp. 74-89.

Morgan, J. and S. Macdonald (2018), 'De-growing museum collections for new heritage futures', International Journal of Heritage Studies, https://doi.org/10.1080/13527258 .2018.1530289

Morton, T. (2013), Hyperobjects: Philosophy and Ecology after the End of the World, Minneapolis, MN: University of Minnesota Press.

Morton, T. (2017), Humankind: Solidarity with Non-Human People, London: Verso.

Mouffe, C. (2013), Agonistics: Thinking the World Politically, London: Verso.

Pereira Roders, A. and F. Bandarin (eds) (2019), Reshaping Urban Conservation: The Historic Urban Landscape Approach in Action, Singapore: Springer.

Puig de la Bellacasa, M. (2017), Matters of Care: Speculative Ethics in More Than Human Worlds, Minneapolis, MN: University of Minnesota Press.

Ranciere, J. (1999), Disagreement: Politics and Philosophy, Minneapolis, MN: University of Minnesota Press.

Sabbioni, C., P. Brimblecombe and M. Cassar (2010), The Atlas of Climate Change Impact on European Cultural Heritage: Scientific Analysis and Management Strategies, London and New York: Anthem Press.

Salazar, B.N. (2010), 'The glocalisation of heritage through tourism: Balancing standardisation and differentiation', in S. Labadi and C. Long (eds), Heritage and Globalisation, London: Routledge, pp. 130-47. 
Sham, D.H.-M. (2017), 'Imagining a new urban commons: Heritage preservation as/ and community movements in Hong Kong', Asia Research Institute Working Paper Series No. 260. Accessed 15 October 2019 at: http://www.nus.ari.edu.sg/pub/wps .htm

Silverman, H. (2011), Contested Cultural Heritage: Religion, Nationalism, Erasure, and Exclusion in a Global World, New York: Springer-Verlag.

Smith, L. (2006), Uses of Heritage, London: Routledge.

Swyngedouw, E. (2010), 'Apocalypse forever? Post-political populism and the spectre of climate change', Theory Culture Society, 27, 213-32.

Till, E.K. (2012), 'Wounded cities: Memory-work and a place-based ethics of care', Journal of Political Geography, 31 (2012), 3-14.

Timothy, D. and S. Boyd (2006), 'Heritage tourism in the 21st century: Valued traditions and new perspectives', Journal of Heritage Tourism, 1 (1), 1-16.

Tolia-Kelly, P.D., E. Waterton and S. Watson (2016), Heritage, Affect and Emotion: Politics, Practices and Infrastructures, Abingdon: Routledge.

Tunbridge, J.E. and G.J. Ashworth (1996), Dissonant Heritage: The Management of the Past as a Resource in Conflict, New York: Wiley.

Van Laerhoven, F. and E. Ostrom (2007), 'Traditions and trends in the study of the commons', International Journal of the Commons, 1 (1), 3-28.

Vecco, M. and M. Piazzai (2015), 'Deaccessioning of museum collections: What do we know and where do we stand in Europe?', Journal of Cultural Heritage, 16 (2), 221-7.

Vergo, P. (ed.) (1989), The New Museology, London: Reaktion Books.

Waterton, E. and L. Smith (2010), 'The recognition and misrecognition of community heritage', International Journal of Heritage Studies, 16 (1), 4-15.

Waterton, E. and S. Watson (2013), 'Framing theory: Towards a critical imagination in heritage studies', International Journal of Heritage Studies, 19 (6), 546-61.

Winter, T. (2013), 'Clarifying the critical in critical heritage studies', International Journal of Heritage Studies, 19, 532-45. 